\title{
Levels and Potential Health Hazards of Chlorinated Pesticides in Surface Water Samples of Charsadda Area of Pakistan Using SPME-GC-ECD Technique
}

\author{
Muhammad Ismail ${ }^{1, *}$, Sultan Alam ${ }^{2}$, Muhammad Sufaid Khan ${ }^{2} \mathbb{D}$, Luqman Ali Shah ${ }^{3} \mathbb{D}$, S. M. Mukaram Shah ${ }^{4}$, \\ Muhammad Wahab ${ }^{5}$, Gul Rukh ${ }^{1}$, Najeeb ur Rahman ${ }^{2}$, Noor Rehman ${ }^{6}$, Noor ul Amin ${ }^{7}$ (D), Juris Burlakovs ${ }^{8}$ (D), \\ Anna Kallistova ${ }^{9}$, Nikolai Pimenov ${ }^{9}$, Zane Vincevica-Gaile ${ }^{10}$, Yahya Jani ${ }^{11}$ (D), Muhammad Zahoor ${ }^{12, *(D)}$ and Ivar Zekker ${ }^{13, *}$
}

Citation: Ismail, M.; Alam, S.; Khan, M.S.; Shah, L.A.; Shah, S.M.M.; Wahab, M.; Rukh, G.; Rahman, N.u.; Rehman, N.; Amin, N.u.; et al. Levels and Potential Health Hazards of Chlorinated Pesticides in Surface Water Samples of Charsadda Area of Pakistan Using SPME-GC-ECD Technique. Water 2021, 13, 2468. https://doi.org/10.3390/w13182468

Academic Editor:

Helvi Heinonen-Tanski

Received: 21 July 2021

Accepted: 2 September 2021

Published: 8 September 2021

Publisher's Note: MDPI stays neutral with regard to jurisdictional claims in published maps and institutional affiliations.

Copyright: (C) 2021 by the authors Licensee MDPI, Basel, Switzerland. This article is an open access article distributed under the terms and conditions of the Creative Commons Attribution (CC BY) license (https:/ / creativecommons.org/licenses/by/ $4.0 /)$.
1 Department of Chemistry, Women University Swabi, Swabi 23430, KPK, Pakistan; zmanalmanal44@gmail.com

2 Department of Chemistry, University of Malakand, Chakdara Dir Lower 18800, KPK, Pakistan; dr.sultanalam@yahoo.com (S.A.); sufaidkhan1984@gmail.com (M.S.K.); nrnajeeb@yahoo.com (N.u.R.)

3 National Center of Excellence in Physical Chemistry (NCE), University of Peshawar, Peshawar 230000, Pakistan; luqman_alisha@yahoo.com

4 Department of Pharmacy, University of Swabi, Swabi 23430, KPK, Pakistan; mukaramshah@uoswabi.edu.pk

5 Department of Botany, Woman University Swabi, Swabi 23430, Pakistan; m_wahabdir@yahoo.com

6 Department of Chemistry, Shaheed Benazir Bhutto University, Sheringal Dir Upper 18800, Pakistan; noorrehman@sbbu.edu.pk

7 Department of Chemistry, Abdul Wali Khan University, Mardan 23200, Pakistan; noorulamin_xyz@yahoo.com

8 Institute of Forestry and Rural Engineering, Estonian University of Life Sciences, 5 Kreutzwaldi St., 51006 Tartu, Estonia; Juris.burlakovs@emu.ee

9 Research Centre of Biotechnology of the Russian Academy of Sciences, Winogradsky Institute of Microbiology, Leninsky Pro-Spect, 33, Build. 2, 119071 Moscow, Russia; kallistoanna@mail.ru (A.K.); npimenov@mail.ru (N.P.)

10 Department of Environmental Science, University of Latvia, LV-1004 Riga, Latvia; zane.gaile@lu.lv

11 Department of Urban Studies, Unit of Built Environment and Environmental Science, Malmö University, 21119 Malmö, Sweden; yahya.jani@mau.se

12 Department of Biochemistry, University of Malakand, Chakdara Dir Lower 18800, KPK, Pakistan

13 Institute of Chemistry, University of Tartu, 14a Ravila St., 50411 Tartu, Estonia

* Correspondence: ismail_wazirs@yahoo.com (M.I.); mohammadzahoorus@yahoo.com (M.Z.); ivar.zekker@ut.ee (I.Z.)

Abstract: In the present study, we determined the levels of chlorinated pesticide residues in surface water samples collected from the Charsadda district (KPK, Pakistan). SPME-GC-ECD with COMBI PAL CTC autosampler was used for extraction and analysis of 20 organochlorine pesticides in the collected water samples. For maximum efficiency of the SPME procedure, several parameters were studied, including the extraction and desorption time of the fiber, solution $\mathrm{pH}$, agitation of samples, and stirring speed, etc. This method showed good liner response, with $\mathrm{R}^{2}$ values in the range of 0.9887 to 0.9999 for all pesticides. This method also provided good percent recoveries at $1 \mu \mathrm{g} \mathrm{L}{ }^{-1}(87.5$ to $106.0 \%)$ and at $2 \mu \mathrm{g} \mathrm{L}^{-1}(88.5$ to $109.2 \%)$. Lower limits of detection for all 20 chlorinated pesticides were found to be lower than their maximum permissible contamination levels. Approximately $50 \%$ of the surface water samples collected from the Charsadda district were found to be contaminated with the pesticides $\gamma$-BHC, heptachlor, aldrin and dieldrin, with maximum concentrations of 0.023 , $0.108,0.014$ and $0.013 \mu \mathrm{g} \mathrm{L}^{-1}$, respectively. For adults and children, the cancer risk from water due to contamination by various pesticides ranged from 0 to $33.29 \times 10^{-6}$. The non-carcinogenic risk from each pollutant in the water samples of the Charsadda district was found to be in the order of heptachlor $>$ aldrin $>$ dieldrin $>\gamma$-BHC. However, the pesticides $\alpha$-BHC, $\beta$-BHC, heptachlor epoxide, chlordane, endrin, 4, $4^{\prime}$-DDD, endrin ketone, 4,4'-DDT, endosulfan sulfate and methoxychlor were not detected in any of the surface water samples of investigated in the present study.

Keywords: chlorinated pesticides; SPME; GC-ECD; water samples; cancer risk 


\section{Introduction}

Pesticides are mostly used for preventing, fighting and eliminating a variety of pests, such as weeds, insects, rodents, and fungi [1]. However, their extensive use in agriculture worldwide has led to widespread contamination of natural waters and presence of pesticides across the environment [1,2]. A large number of pesticides with different chemical compositions are currently used all over the world for agricultural purposes. Their widespread use has meant that pesticide residues have been detected in various environmental matrices, such as soil, water and air by several researchers [3-18].

Pesticides are divided into many classes, the most important being organochlorine pesticides (OCPs) and organophosphorus pesticides (OPPs) [19]. OCPs are very stable substances that resist biodegradation in the environment $[20,21]$. Therefore, they bioaccumulate, getting recycled through the food web to produce a significant magnification of the original concentration at the end of the chain. OCPs are one of the most persistent organic micro pollutants present in water. As a result of their toxicity and ability to bioaccumulate, they are a possible risk both to human health and the environment [21].

The contamination of water due to extensive use of pesticides for agricultural purposes a serious threat to the environment and human health. Contamination from OCPs is particularly significant, due to their persistence in the environment for a long time, and the high toxicity to aquatic life and human health. Contamination of water by pesticides may occur due to direct run off, careless disposal of empty containers, leaching, misuse, equipment washing, etc. [22]. Along with the dangers for environmental and human health posed by their bioaccumulation and biomagnifying effects in the food chain, OCPs also produce reproductive and carcinogenic impacts in animals and human beings [23].

Agriculture is the largest sector of Pakistan's economy. It presently accounts for $21 \%$ of the GDP. Agriculture provides good employment opportunities for $45 \%$ of the labor force, and $60 \%$ of the country's rural population depends upon the sector for their livelihood. Agriculture has a vital role in ensuring food security, reducing poverty, developing overall economic growth and the transformation towards industrialization. The total import of insecticides was estimated (by weight) during 2009-2010 (38,227 Tons), 2010-2011 (36,183 Tons) and 2011-2012 (22,510 Tons), and had a market value of Rs. 13,473 million (109.13 million Euro), Rs. 13,178 million (106.74 million Euro) and Rs. 8531 million (69.10 million Euro), respectively [24].

The growth rates for insecticides, herbicides and fungicides in Pakistan over the last 10 years were $3 \%, 5 \%$ and $2 \%$, respectively. On average, $63 \%$ of the pesticides were used for crops while the rest were used for fruits and vegetables. On average, $75 \%$ of pesticide consumption took place in Punjab, followed by $22 \%$ in Sindh. However, pesticide use in both Punjab and Sindh is gradually declining, due to a decrease in pesticide application to cotton crops [25]. Of the pesticides used in Pakistan, $74 \%$ were insecticides, $14 \%$ were herbicides, $9 \%$ were fungicides, $2 \%$ were acaricides and $1 \%$ were fumigants [26]. It has been estimated that almost $80-90 \%$ of pesticides were consumed on cotton crops, while the remaining 10-20\% were used on sugarcane, paddy, fruits, and vegetables [27].

Early estimates by the World Health Organization (WHO) suggested that one million pesticide poisonings (unintentional acute cases) occurred annually worldwide [28]. This figure only included more serious cases and those registered in hospitals. The WHO has since stated that the cases of poisonings have been underestimated, and there may be a significant increase in the extent of poisonings [29]. Globally, an estimated 20,000 people were killed in 1990 from unintentional pesticide poisonings [28]. More recent statistics and WHO data since 2008 show that, annually, 346,000 people die worldwide due to unintentional pesticide poisonings, two-thirds of them in developing countries [30,31].

In the present study, we identify residues of approximately 20 types of OCPs in surface water samples from Charsadda district, through the use of solid phase micro-extraction (SPME), in combination with gas chromatograph (GC) with electron capture detection (ECD). Some of these OCPs are banned and not produced in Pakistan, but are being used unofficially. 


\section{Materials and Methods}

\subsection{Sampling Area}

Charsadda is a district of Khyber Pakhtunkhwa (KPK) province in Pakistan. Charsadda lies between $34^{\circ} 03^{\prime}$ and $34^{\circ} 38^{\prime}$ North latitudes to $71^{\circ} 28^{\prime}$ and $71^{\circ} 53^{\prime}$ East longitudes Charsadda is located in the west of the Khyber Pakhtunkhwa and is bounded by Malakand district to the North, Mardan district to the East, Nowshera and Peshawar districts to the South and the Mohmand Agency to the West. The total area of the district is approximately 996 square kilometers (243,753 acres). The total cultivated area is 210,255 acres (61\%) and the irrigated area is 180,339 acres, i.e., $86 \%$ of the total cultivated area. Three rivers pass through Charsadda: the River Jindi, the Swat River and the Kabul River. These are the main sources of irrigation for Charsadda. The three rivers then merge and join the Indus River. The population of Charsadda was 1.7 million in the year 2000. Charsadda has a density of 1081 people/sq.km. The main crops in Charsadda are tobacco, sugarcane, sugar beet, wheat and maize, etc. The major vegetables of Charsadda are potato, tomato, cabbage, okra and spinach, while the main fruits are apricot, citrus, plum, strawberry and pears. The Charsadda district is a purely agricultural area and is very fertile. Farmers use extensive amounts of pesticides on crops, fruits and vegetables for the control of various pests. Therefore, in this study to improve public awareness, we selected Charsadda district for the analysis of contamination from 20 organochlorine pesticides in surface water samples. Various surface water sample sites in the Charsadda area given in Figure 1.

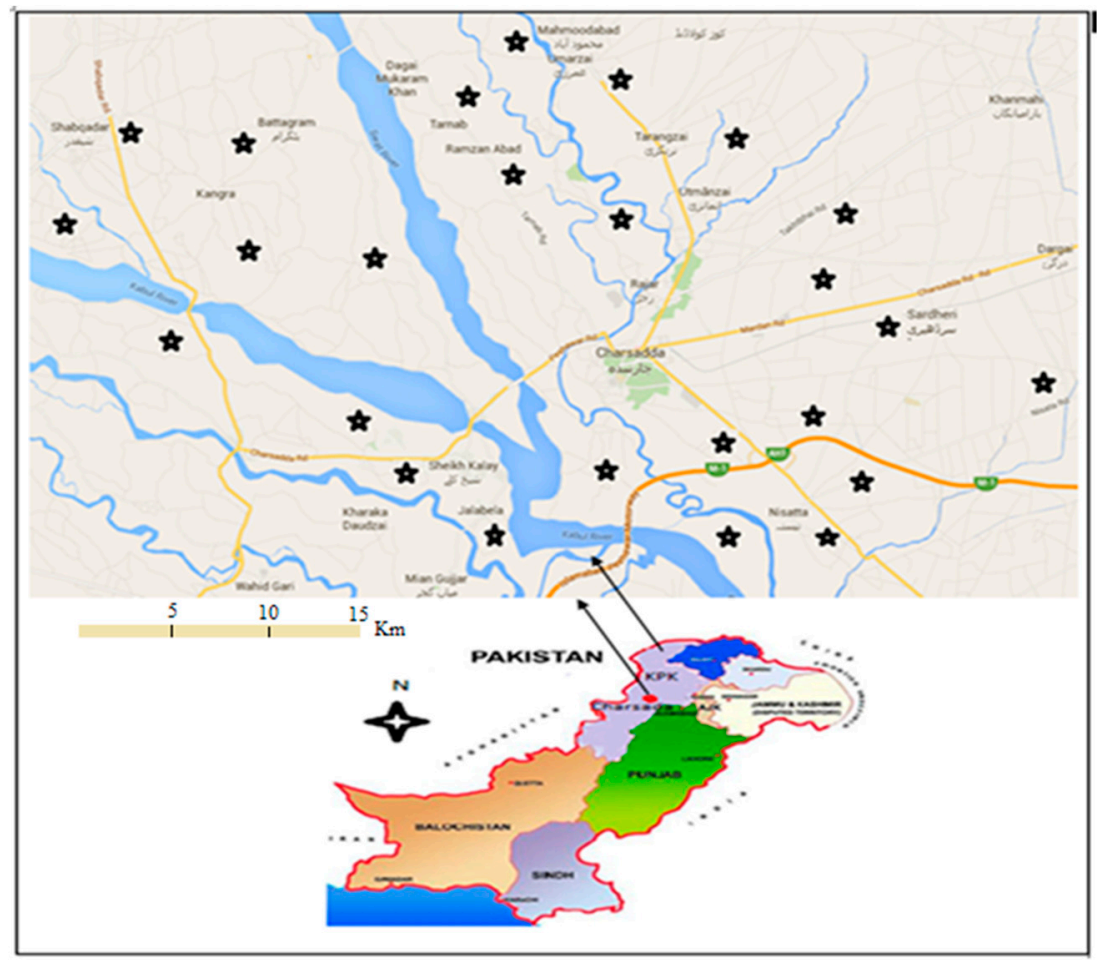

Figure 1. Map of Charsadda district locating various water sampling sites.

\subsection{Extraction of Pesticides from Water}

The pesticide concentrations present in contaminated water samples are very low, and efficient extraction from water samples is needed to determine pesticide contamination in water matrixes. Therefore, for the analysis of pesticides in water samples, a good extraction and concentration method is required [32,33]. Solid-phase micro-extraction (SPME) is a new, convenient and efficient extraction method for use with liquid samples. This method needs no solvent and the use of sophisticated equipment can be avoided. SPME decreases sample analysis expenditures and time required for sample preparation. It includes the immersion of a fused silica rod coated with a stationary phase (called fiber) in 
the solution [32,34]. The fiber adsorbs pesticides, which are then desorbed from the fiber in the GC hot injector (for gas chromatographic analysis) or by solvent desorption (for HPLC). SPME is an easy sample preparation technique that has received increasing attention since its first development in 1990 [35,36].

\subsection{Standards and Reagents}

The organochlorine pesticide mixture (standards) was obtained from Supelco (Bellefonte, PA, USA) with $>99 \%$ purity. The methanol and acetonitrile (HPLC grade) were purchased from Merck (Darmstadt, Germany). All the chemical reagents used (Per chloric acid and sodium hydroxide) were high-purity analytical grade reagents purchased from Sigma-Aldrich, St Louis, MO, USA. All aqueous solutions were prepared in ultra-pure water. A Milli-Q water purification system (Millipore, Bedford, MA, USA) was used for ultra-pure water. High purity nitrogen gas ( $99.99 \%$ purity) was used in the present study.

\subsection{Solutions Preparation}

Stock solution ( $10 \mathrm{mg} \mathrm{L}^{-1}$ ) containing each of the 20 organochlorine pesticides was prepared from $2000 \mathrm{mg} \mathrm{L}^{-1}$ standard solution (Supelco, Bellefonte, PA, USA) in methanol and stored at $4{ }^{\circ} \mathrm{C}$. For calibration, fresh standard working solutions of various concentrations i.e., $0.01,0.05,0.1,0.3,0.5,1$ and $2 \mu \mathrm{g} \mathrm{L}^{-1}$ were prepared from stock solution in ultra-pure water containing all 20 pesticides. Calibration plots were used for quantitative analysis of pesticides in water samples.

\subsection{Samples Collection}

The agricultural Charsadda district was selected for the analysis of pesticides in water samples. A total of 30 surface water samples were collected from various sites in Charsadda. All samples were collected in $100 \mathrm{~mL}$ new and disposable plastic bottles. After collection, water samples were first filtered with Whatman filter paper to remove dust and particulate matter, and then with $0.45 \mu \mathrm{m}$ filter paper for further purification. After filtration, water samples were stored in $20 \mathrm{~mL}$ glass vials (made by Agilent Technologies, Santa Clara, CA, USA) for pesticide analysis to be performed by gas chromatograph (GC). Glass vials were washed with glass cleaner detergent and a brush and then rinsed properly with running tap water. Vials were then rinsed and well shaken with an ethanol:distal water mixture (20:80) before being rinsed with ultra-pure water (milli $Q$ water). Finally, vials were placed for few hours in an oven at $120^{\circ} \mathrm{C}$ for dryness purposes. A DVB-PDMS fiber was used for pesticide extraction from water samples.

\subsection{Analytical Instrumentation and Operating Conditions for GC-ECD}

The solid-phase micro-extraction (SPME) fiber used was DVB-PDMS (Supelco, Bellefonte, PA, USA). The fiber was conditioned before the first application by using a GC hot injector at $250{ }^{\circ} \mathrm{C}$ and detector at $300{ }^{\circ} \mathrm{C}$ for $1 \mathrm{~h}$. The injector, column and detector were cleaned to remove any contamination for $30 \mathrm{~min}$ at 260,280 and $310^{\circ} \mathrm{C}$, respectively. A blank test was made by injecting 1-2 microliters of highly pure ethanol and running on GC, followed by checks for the presence of any possible contamination in the injector, column and detector of the GC-ECD. After clearance, water samples were analyzed on GC for the determination of various pesticides.

All chromatographic analysis of chlorinated pesticides was carried out on an Agilent gas chromatograph (6890 N series, Agilent Technologies, Palo Alto, CA, USA) equipped with ECD (electron capture detector) and a split/split less injector. The injector was used in split less mode. Chromatographic separations were performed using HP-5 fused-silica capillary column, $30 \mathrm{~m} \times 0.32 \mathrm{~mm}$ id and $0.25 \mu \mathrm{m}$ film thickness (5\% diphenyl-95\% dimethyl siloxane coating) from Agilent. The operating GC conditions for the analysis of organochlorine pesticides in water samples were as follows: initial oven temperature was $80^{\circ} \mathrm{C}(4 \mathrm{~min})$ and then it was increased at $15^{\circ} \mathrm{C} \mathrm{min}-1$ to $215^{\circ} \mathrm{C}$ (for $30 \mathrm{sec}$ ). Then it was raised again at $2{ }^{\circ} \mathrm{C} \mathrm{min}-1$ to $230{ }^{\circ} \mathrm{C}$ and remained constant for 3 min at this temperature. 
After this it was increased at $10{ }^{\circ} \mathrm{C} \mathrm{min}^{-1}$ to $260{ }^{\circ} \mathrm{C}$. The detector temperature was $300{ }^{\circ} \mathrm{C}$ and the injector temperature was $250^{\circ} \mathrm{C}$. A single GC run was completed in $28 \mathrm{~min} . \mathrm{N}_{2}$ gas $\left(99.999 \%\right.$ purity) was used as a make-up and carrier gas at a flow rate of $45 \mathrm{~mL} \mathrm{~min}^{-1}$ and $1 \mathrm{ml} \mathrm{min}^{-1}$, respectively. For fiber, an extraction time of $45 \mathrm{~min}$, desorption time of 2 min and agitator speed of $250 \mathrm{rpm}$ were selected. When using the CTC autosampler, the SPME fiber is fixed in the holder assembly of the autosampler. The autosampler immersed the SPME fiber in the $20 \mathrm{~mL}$ vials for $45 \mathrm{~min}$ with agitation. The SPME fiber then extracted the pesticides from water samples. After $45 \mathrm{~min}$, SPME fiber was removed from the vial and directly injected to the GC injector, where hot flow of nitrogen gas at $250{ }^{\circ} \mathrm{C}$ desorbed the organics (pesticides) from the SPME fiber to the injector, and then to the GC column for separation.

Figure 2 shows a typical chromatogram of 20 standard organochlorine pesticides using the above-mentioned GC conditions and using SPME fiber.

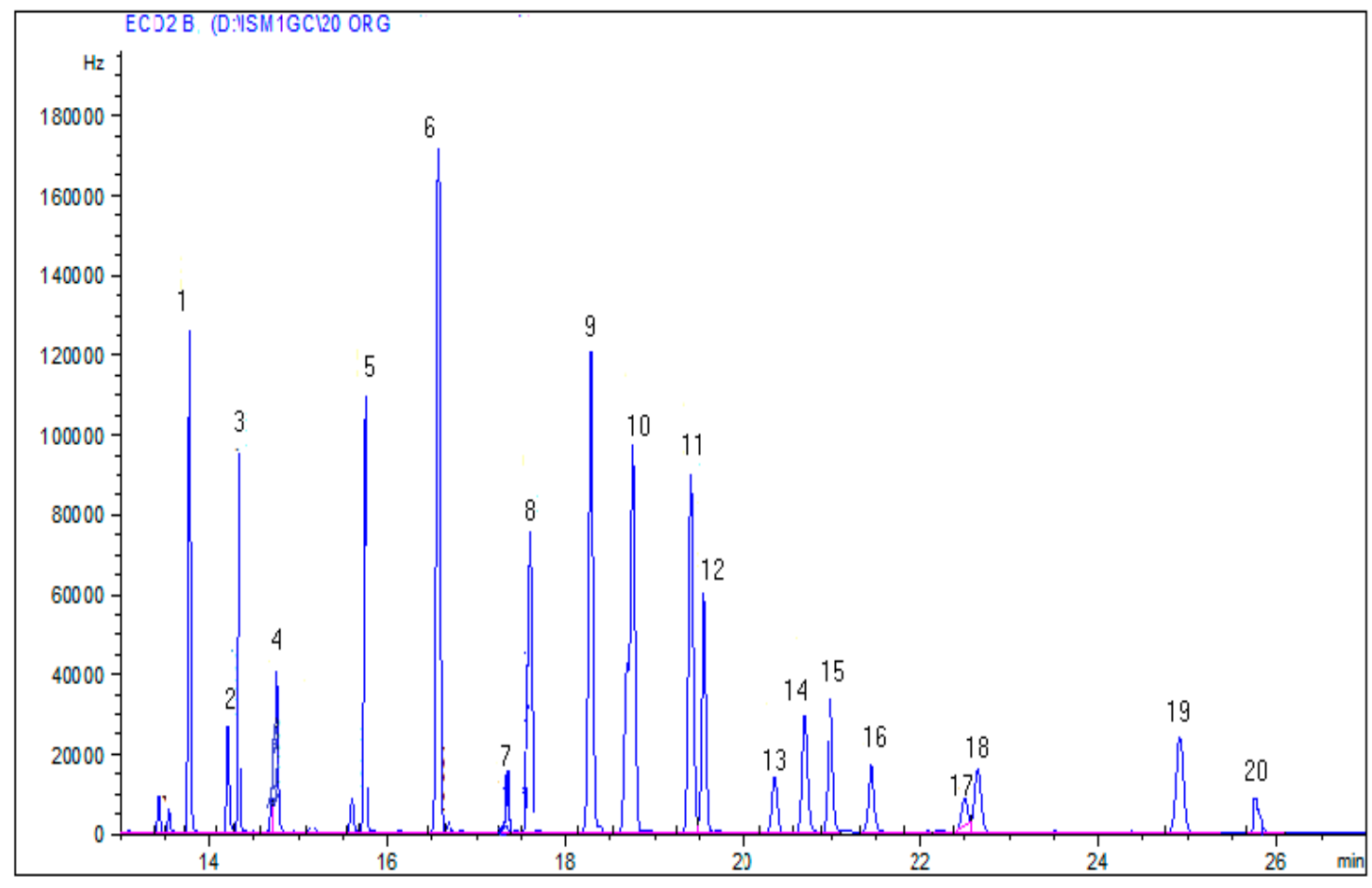

Figure 2. A typical chromatogram for 20 organochlorine pesticides standard and peaks identification: (1) $\alpha$-BHC, (2) $\beta$-BHC, (3) $\gamma$-BHC, (4) $\delta$-BHC, (5) heptachlor, (6) aldrin, (7) heptachlor epoxide, (8) $\gamma$-chlordane, (9) $\alpha$-chlordane, (10) endosulfan I, (11) 4,4'-DDE, (12) dieldrin, (13) endrin, (14) endosulfan II, (15) 4,4'-DDD, (16) endrin aldehyde, (17) endrin ketone, (18) 4,4'-DDT, (19) endosulfan sulfate, (20) methoxychlor.

\subsection{Health Risk Assessment Model}

The health risk assessment model is a method used to estimate the nature and probability of adverse health effects in humans who may be exposed to toxic contamination in the environmental media, presently or in the future. There are several mechanisms of exposure to OCPs contamination, however, the most important one is oral exposure $[37,38]$. In the present study, the US EPA health risk assessment model is applied for the approximation of carcinogenic and non-carcinogenic risks for adults and children consuming underground water as their drinking water source [39]. To estimate human exposure to contaminants, chronic daily intake (CDI) is used and can be calculated with the following formula [40].

$$
\mathrm{CDI}=\frac{\mathrm{C} \times \mathrm{IR} \times \mathrm{EF} \times \mathrm{ED}}{\mathrm{BW} \times \mathrm{AT}}
$$


where $\mathrm{C}=$ chemical concentration in water $\left(\mathrm{mg} \mathrm{L}^{-1}\right) ; \mathrm{IR}=$ water ingestion rate $\left(1 \mathrm{day}^{-1}\right)$ (for children: $\mathrm{IR}=1.0$; for adults: $\mathrm{IR}=2.0$ ); $\mathrm{EF}=$ the exposure frequency ( 350 days year $^{-1}$ ); $\mathrm{ED}=$ exposure duration (year) (for children: $\mathrm{ED}=6$; for adults: $\mathrm{ED}=70$ ); $\mathrm{BW}=$ bodyweight $(\mathrm{kg})$ (for children: $\mathrm{BW}=14$; for adults: $\mathrm{BW}=60$ ); $\mathrm{AT}=$ average lifespan (days) (for children: AT $=2190$; for adults: AT $=25,550$ ).

According to the US EPA exposure factors handbook, carcinogenic risk (R) can be calculated as follows [41];

$$
\mathrm{R}=\mathrm{CDI} \times \mathrm{SF}
$$

where CDI is the chronic daily intake from the oral exposure route ( $\mathrm{mg} \mathrm{kg}^{-1}$ per day), SF is the slope factor of the contaminant via the oral exposure route $\left[\left(\mathrm{mg} \mathrm{kg}^{-1} \text { per day }\right)^{-1}\right]$. Non-carcinogenic risk estimated by hazard quotient (HQ) is calculated using the following formula;

$$
\mathrm{HQ}=\mathrm{CDI} / \mathrm{R}_{\mathrm{f}} \mathrm{D}
$$

where $\mathrm{R}_{\mathrm{f}} \mathrm{D}$ (mg kg $\mathrm{m}^{-1}$ per day) is the reference dose of the contaminant via oral exposure route. The values of slope factor and reference dose (Table 1) for OCPs are obtained from the US EPA integrated risk information System [42].

Table 1. Health risks due to organochlorine pesticides for adults and children in the Charsadda district through surface

\begin{tabular}{|c|c|c|c|c|c|c|}
\hline \multirow{2}{*}{ Pesticide } & \multirow{2}{*}{$\begin{array}{l}\mathrm{SF} /\left[\left(\mathrm{mg} \mathrm{kg} \mathbf{k g}^{-1}\right.\right. \\
\left.\text { per Day })^{-1}\right]^{*}\end{array}$} & \multirow{2}{*}{$\begin{array}{c}\mathrm{R}_{\mathrm{f}} \mathrm{D} /(\mathrm{mg} \mathrm{kg} \\
\text { per Day) }\end{array}$} & \multicolumn{2}{|c|}{ Cancer Risk $\left(10^{-6}\right)$} & \multicolumn{2}{|c|}{ Hazard Quotient $\left(10^{-2}\right)$} \\
\hline & & & (for Children) & (for Adults) & (for Children) & (for Adults) \\
\hline$\alpha-\mathrm{BHC}$ & 6.3 & $5.0 \times 10^{-4}$ & 0 & 0 & 0 & 0 \\
\hline$\beta-\mathrm{BHC}$ & 1.8 & $2.0 \times 10^{-4}$ & 0 & 0 & 0 & 0 \\
\hline$\gamma-\mathrm{BHC}$ & 1.3 & $3.0 \times 10^{-4}$ & $0-2.05$ & 0.96 & 0.52 & 0.24 \\
\hline$\delta-\mathrm{BHC}$ & / & / & 0 & 0 & & \\
\hline Heptachlor & 4.5 & $5.0 \times 10^{-4}$ & $0-33.29$ & 15.53 & 1.48 & 0.69 \\
\hline Aldrin & 17 & $3.0 \times 10^{-5}$ & $0-16.30$ & 7.61 & 3.20 & 1.49 \\
\hline $\begin{array}{l}\text { Heptachlor } \\
\text { poxide }\end{array}$ & 9.1 & $1.3 \times 10^{-5}$ & 0 & 0 & 0 & 0 \\
\hline$\gamma$-Chlordane & / & / & 0 & 0 & 0 & 0 \\
\hline$\alpha$-Chlordane & / & / & 0 & 0 & 0 & 0 \\
\hline Endosulfan I & / & / & 0 & 0 & 0 & 0 \\
\hline $4,4^{\prime}-\mathrm{DDE}$ & 0.34 & / & 0.47 & 0.22 & - & - \\
\hline Dieldrin & 16 & $5.0 \times 10^{-5}$ & 14.25 & 6.65 & 1.78 & 0.83 \\
\hline Endrin & / & $3.0 \times 10^{-4}$ & 0 & 0 & 0 & 0 \\
\hline Endosulfan II & / & / & 0 & 0 & 0 & 0 \\
\hline $4,4^{\prime}-\mathrm{DDD}$ & 0.24 & $2.0 \times 10^{-3}$ & 0 & 0 & 0 & 0 \\
\hline $\begin{array}{l}\text { Endrin } \\
\text { aldehyde }\end{array}$ & / & $3.0 \times 10^{-4}$ & - & - & 0.68 & 0.32 \\
\hline Endrin ketone & / & / & 0 & 0 & 0 & 0 \\
\hline $4,4^{\prime}$-DDT & 0.34 & $5.0 \times 10^{-4}$ & 0 & 0 & 0 & 0 \\
\hline $\begin{array}{l}\text { Endosulfan } \\
\text { sulfate }\end{array}$ & / & / & 0 & 0 & 0 & 0 \\
\hline Methoxychlor & / & / & 0 & 0 & 0 & 0 \\
\hline
\end{tabular}
water.

* Toxicological parameters for some organochlorine pesticides. /: no given parameter value.

\section{Results and Discussion}

\subsection{Optimization of Experimental Conditions}

The GC-ECD chromatogram using solid-phase micro-extraction (SPME) for the 20 organochlorine pesticides standard is given in Figure 2. All chlorinated pesticides were eluted in $28 \mathrm{~min}$ and were well resolved under the selected GC operating conditions as mentioned in Section 2.6. The extraction of pesticides from water was carried out in $20 \mathrm{~mL}$ glass vials by dipping the SPME fiber in the solution using a COMBI PAL CTC autosampler. For maximum efficiency in the SPME procedure, several variables, such as the fiber extraction and desorption steps, needed to be optimized. The various parameters 
studied here were the fiber extraction and desorption time, solution $\mathrm{pH}$, agitation of samples, stirring speed and splitless time. The $\mathrm{pH}$ was adjusted with $0.1 \mathrm{M} \mathrm{HCl}$ and $0.1 \mathrm{M}$ $\mathrm{NaOH}$ by measurement with a digital $\mathrm{pH}$ meter (Newmet, $\mathrm{pH}$ /ISE Meter $\mathrm{pH}-250 \mathrm{~L}$, Korea). After the extraction of pesticides by the SPME fiber, the pesticides were injected to the column through thermal desorption in the injector of the GC. To achieve good results, all investigations were performed in triplicate and average values were obtained.

The parameters selected for SPME fiber were: a fiber extraction time of $45 \mathrm{~min}$, desorption time of $2 \mathrm{~min}$, agitator speed of $250 \mathrm{rpm}$, and $\mathrm{pH}$ of 6.2. These selected parameters were used to develop the analytical procedure and for the chlorinated pesticides analysis in real water samples.

\subsection{Method Validation}

The SPME-GC-ECD technique is an excellent and suitable analytical method to determine a large number of chlorinated pesticides in real water samples. The analytical parameters applied to validate the method were linearity, selectivity, accuracy, precision and detection limits. Calibration plots were used to determine various compounds in the water samples by plotting peak area versus compound concentrations. The linearity was observed at different concentrations using the least square regression method. The calibration plots of 20 organochlorine compounds at various concentrations $\left(0.01 \mu \mathrm{g} \mathrm{L}^{-1}\right.$ to $1 \mu \mathrm{g} \mathrm{L}^{-1}$ ) provided good linear correlation, with $R^{2}$ values in the range of 0.9887 to 0.9999 . Lower limits of detection (LOD) (the lowest concentration of an analyte in a sample that can be detected by analytical instrument, however, not necessarily quantified under the stated conditions of the test) were obtained on the basis of a signal-to-noise ratio $(\mathrm{S} / \mathrm{N})$ of 3:1. To measure the signal-to-noise ratio of the instrument for various pesticides, very low concentrations $\left(0.001,0.002,0.003,0.004,0.005,0.006,0.007\right.$ and $\left.0.008 \mu \mathrm{g} \mathrm{L}^{-1}\right)$ of various pesticides were run on the GC. The $R^{2}$ values, lower limits of detection and WHO guideline values are given in Table 2 . The LOD for all 20 organochlorine pesticides were calculated in the range of $0.002-0.03 \mu \mathrm{g} \mathrm{L}^{-1}$, and were found to be lower than their maximum permissible contamination levels. Various researchers have determined that the LOD for different organochlorine pesticides ranges from 0.001-0.025 $\mathrm{g} \mathrm{L} \mathrm{L}^{-1}$ [43], 0.008-0.020 $\mu \mathrm{g} \mathrm{L}^{-1}$ [19], and $0.039-0.340 \mu \mathrm{g} \mathrm{L}^{-1}$ (EPA 525.2 method) [44].

Table 2. The Linear range, $R^{2}$ values, lower limits of detection and WHO guideline values for selected pesticides.

\begin{tabular}{|c|c|c|c|c|c|c|}
\hline \multirow{2}{*}{ Compound } & \multirow{2}{*}{$\begin{array}{c}\text { Correlation } \\
\text { Coefficient (r) }\end{array}$} & \multicolumn{4}{|c|}{ Lower Limits of Detection $\left(\mu g \mathrm{~L}^{-1}\right)$} & \multirow{2}{*}{$\begin{array}{c}\text { Guide Line } \\
\text { Values }\left(\mu g L^{-1}\right)\end{array}$} \\
\hline & & Present Study & $\begin{array}{c}\text { Cortada et al., } \\
2009\end{array}$ & $\begin{array}{l}\text { Golfinopoulos } \\
\text { et al., } 2003\end{array}$ & EPA $525.2^{b}$ & \\
\hline$\alpha-\mathrm{BHC}$ & 0.9985 & 0.003 & 0.003 & 0.008 & 0.110 & - \\
\hline$\beta-\mathrm{BHC}$ & 0.9996 & 0.006 & 0.005 & 0.020 & 0.085 & - \\
\hline$\gamma-\mathrm{BHC}$ & 0.9998 & 0.002 & 0.008 & 0.008 & 0.084 & $2^{\mathrm{c}}, 0.05^{\mathrm{d}}, 0.2^{\mathrm{e}}$ \\
\hline$\delta-\mathrm{BHC}$ & 0.9995 & 0.003 & 0.006 & 0.008 & 0.049 & $0.05^{\mathrm{d}}$ \\
\hline Heptachlor & 0.9997 & 0.004 & 0.007 & 0.008 & 0.061 & $0.03^{c}, 0.4^{e}, 0.05^{d}$ \\
\hline Aldrin & 0.9998 & 0.002 & 0.009 & 0.008 & 0.045 & $0.03^{c}, 0.01^{d}$ \\
\hline $\begin{array}{l}\text { Heptachlor } \\
\text { epoxide }\end{array}$ & 0.9887 & 0.02 & 0.002 & 0.008 & 0.130 & $0.03^{\mathrm{c}}, 0.2^{\mathrm{e}}$ \\
\hline$\gamma$-Chlordane & 0.9996 & 0.003 & - & 0.008 & - & $0.2^{c}, 2^{e}, 0.01^{d}$ \\
\hline$\alpha$-Chlordane & 0.9995 & 0.002 & - & 0.008 & - & $0.2^{\mathrm{c}}, 2^{\mathrm{e}}$ \\
\hline Endosulfan I & 0.9998 & 0.002 & 0.005 & 0.008 & 0.110 & $0.05^{\mathrm{d}}$ \\
\hline $4,4^{\prime}-\mathrm{DDE}$ & 0.9997 & 0.004 & 0.002 & 0.008 & 0.070 & $0.06^{\mathrm{d}}$ \\
\hline Dieldrin & 0.9998 & 0.002 & 0.004 & 0.008 & 0.150 & $0.03^{c}, 0.01^{d}$ \\
\hline Endrin & 0.9947 & 0.004 & 0.004 & 0.008 & 0.340 & $2^{\mathrm{e}}$ \\
\hline Endosulfan II & 0.9998 & 0.003 & 0.025 & 0.008 & 0.074 & $0.05^{\mathrm{d}}$ \\
\hline 4,4'-DDD & 0.9957 & 0.005 & 0.004 & 0.008 & 0.055 & \\
\hline Endrin aldehyde & 0.9976 & 0.004 & 0.001 & 0.008 & 0.150 & \\
\hline Endrin ketone & 0.9968 & 0.003 & 0.004 & 0.008 & - & \\
\hline $4,4^{\prime}$-DDT & 0.9955 & 0.009 & 0.004 & 0.020 & 0.093 & $2^{c}, 0.06^{d}$ \\
\hline $\begin{array}{l}\text { Endosulfan } \\
\text { sulfate }\end{array}$ & 0.9999 & 0.002 & 0.003 & 0.008 & 0.039 & $0.05^{\mathrm{d}}$ \\
\hline Methoxychlor & 0.9899 & 0.03 & 0.001 & 0.008 & 0.130 & $20^{c}, 0.2^{d}$ \\
\hline
\end{tabular}

${ }^{\mathrm{a}}$ Linear range: $0.01-2 \mu \mathrm{g} \mathrm{L}{ }^{-1}$ (calibration points no. $\left.=5\right)^{\mathrm{b}}$ Data taken from U.S. EPA method 525.2 (SPE cartridge-GC-ion trap MS). ${ }^{c}$ WHO guideline values, ${ }^{\mathrm{d}}$ Australia guideline values, ${ }^{\text {e }}$ U.S. EPA maximum permissible level. 
The solid-phase micro-extraction (SPME) technique is a non-exhaustive extraction method. Relative recovery can be calculated as the ratio of peak areas (GC) of spiked water sample extracts to spiked ultra-pure water extracts. The real water samples were spiked with pesticide standards ( 1 and $2 \mu \mathrm{g} \mathrm{L}^{-1}$ ) to perform relative recovery tests, and the results are given in Table 3. The percentage recoveries found at $1 \mu \mathrm{g} \mathrm{L}^{-1}$ and at $2 \mu \mathrm{g} \mathrm{L}{ }^{-1}$ concentrations of pesticides ranged from $87.5 \%$ to $106.0 \%$ and $88.5 \%$ to $109.2 \%$, respectively. At $1 \mu \mathrm{g} \mathrm{L}^{-1}$ level concentration, the minimum percent recovery value found was for $4,4^{\prime}$-DDT $(87.5 \%)$ and maximum percent recovery value found was for $\beta$-BHC $(106.0 \%)$. However, at $2 \mu \mathrm{g} \mathrm{L}^{-1}$ level concentration, the minimum percent recovery value found was for $\alpha$-chlordane $(88.5 \%)$ and maximum percent recovery value found was for endrin ketone $(109.2 \%)$. The percentage recoveries investigated by other researchers for different organochlorine pesticides were ranged from $44.6 \%$ to $121.6 \%$ [19], $75 \%$ to $101 \%$ [43] and $69 \%$ to $107 \%$ [45]. All these results show that the SPME-GC-ECD technique is an excellent and convenient method for chlorinated pesticides analysis in real water samples.

Table 3. Percent recovery values of selected pesticides at two concentration levels by using SPME-GC-ECD technique and comparison with some reported values.

\begin{tabular}{|c|c|c|c|c|c|}
\hline Compound & $\begin{array}{c}1 \mu \mathrm{g} \mathrm{L}^{-1} \\
\text { (Present Study) }\end{array}$ & $\begin{array}{c}2 \mu \mathrm{g} \mathrm{L}^{-1} \\
\text { (Present Study) }\end{array}$ & $\begin{array}{c}\text { Golfinopoulos } \\
\text { et al., } 2003 \\
\left(0.4 \mu \mathrm{g} \mathrm{L}^{-1}\right)\end{array}$ & $\begin{array}{c}\text { Concha-Grana } \\
\text { et al., 2009 } \\
\left(1 \mu \mathrm{g} \mathrm{L}^{-1}\right)\end{array}$ & $\begin{array}{l}\text { Cortada et al., } \\
2009\left(10 \mu \mathrm{g} \mathrm{L}^{-1}\right)\end{array}$ \\
\hline$\alpha-B H C$ & 96.2 & 97.4 & 100.4 & 69 & 101 \\
\hline$\beta-\mathrm{BHC}$ & 106.0 & 108.2 & 121.6 & 90 & 96 \\
\hline$\gamma$-BHC & 98.2 & 102.9 & 100.2 & 73 & 97 \\
\hline$\delta$-BHC & 97.3 & 98.1 & 104.2 & 97 & 86 \\
\hline Heptachlor & 90.6 & 89.4 & 74.5 & 79 & 85 \\
\hline Aldrin & 98.1 & 96.8 & 49.7 & 98 & 81 \\
\hline $\begin{array}{l}\text { Heptachlor } \\
\text { epoxide }\end{array}$ & 89.9 & 91.8 & 67.6 & 102 & 79 \\
\hline$\gamma$-Chlordane & 95.4 & 96.0 & - & 99 & - \\
\hline$\alpha$-Chlordane & 92.8 & 88.5 & - & 100 & - \\
\hline Endosulfan I & 93.5 & 95.1 & 99.7 & 105 & 83 \\
\hline $4,4^{\prime}-\mathrm{DDE}$ & 91.4 & 90.2 & 57.6 & 107 & 81 \\
\hline Dieldrin & 96.9 & 98.4 & 95.5 & 106 & 82 \\
\hline Endrin & 101.1 & 97.0 & 104.0 & 86 & 81 \\
\hline Endosulfan II & 103.8 & 107.9 & 95.2 & 75 & 85 \\
\hline $4,4^{\prime}-\mathrm{DDD}$ & 94.8 & 95.7 & 79.9 & 50 & 84 \\
\hline Endrin aldehyde & 98.2 & 99.5 & 101.1 & 100 & 86 \\
\hline Endrin ketone & 103.7 & 109.2 & 96.9 & 100 & 82 \\
\hline $4,4^{\prime}-\mathrm{DDT}$ & 87.5 & 90.2 & 63.9 & 104 & 75 \\
\hline Endosulfan sulfate & 98.0 & 96.8 & 44.6 & 90 & 82 \\
\hline Methoxychlor & 96.9 & 95.0 & 95.4 & 72 & 75 \\
\hline
\end{tabular}

\subsection{Pesticide Residues in Water Samples}

In the present study, 20 organochlorine pesticide residues in surface water samples collected from the Charsadda district of Khyber Pakhtunkhwa, Pakistan were investigated. A typical chromatogram of pesticides contaminations in surface water samples collected from the Charsadda area is shown in Figure 3.

Among the various pesticides analyzed, $\beta-\mathrm{BHC}, \gamma-\mathrm{BHC}$, heptachlor, aldrin, endosulfan I, dieldrin, 4,4-DDE, endrin aldehyde and endosulfan sulfate were detected in the surface water samples of Charsadda district. The concentrations of pesticides measured by the SPME-GC-ECD method, are given in Table 4 . A total of 30 surface water samples were analyzed for 20 organochlorine pesticide residues. Approximately $50 \%$ of the surface water samples collected from Charsadda were contaminated with the pesticides $\gamma$-BHC, heptachlor, aldrin and dieldrin. The pesticide contaminants found in surface water samples were $\gamma$-BHC (16 samples), heptachlor (17 samples), aldrin (14 samples) and dieldrin (11 samples), with maximum concentrations of $0.023,0.108,0.014$ and $0.013 \mu \mathrm{g} \mathrm{L}{ }^{-1}$, respec- 
tively. The WHO and Australia guideline values and USA maximum contaminant levels for $\gamma$-BHC are $2 \mu \mathrm{g} \mathrm{L}^{-1}, 0.05 \mu \mathrm{g} \mathrm{L}^{-1}$ and $0.2 \mu \mathrm{g} \mathrm{L}^{-1}$, and for heptachlor are $0.03 \mu \mathrm{g} \mathrm{L}^{-1}$, $0.05 \mu \mathrm{g} \mathrm{L}^{-1}$ and $0.4 \mu \mathrm{g} \mathrm{L}^{-1}$, respectively. The $\mathrm{WHO}$ and Australia guideline values for aldrin and dieldrin are $0.03 \mu \mathrm{g} \mathrm{L}^{-1}$ and $0.01 \mu \mathrm{g} \mathrm{L}-1$, respectively.

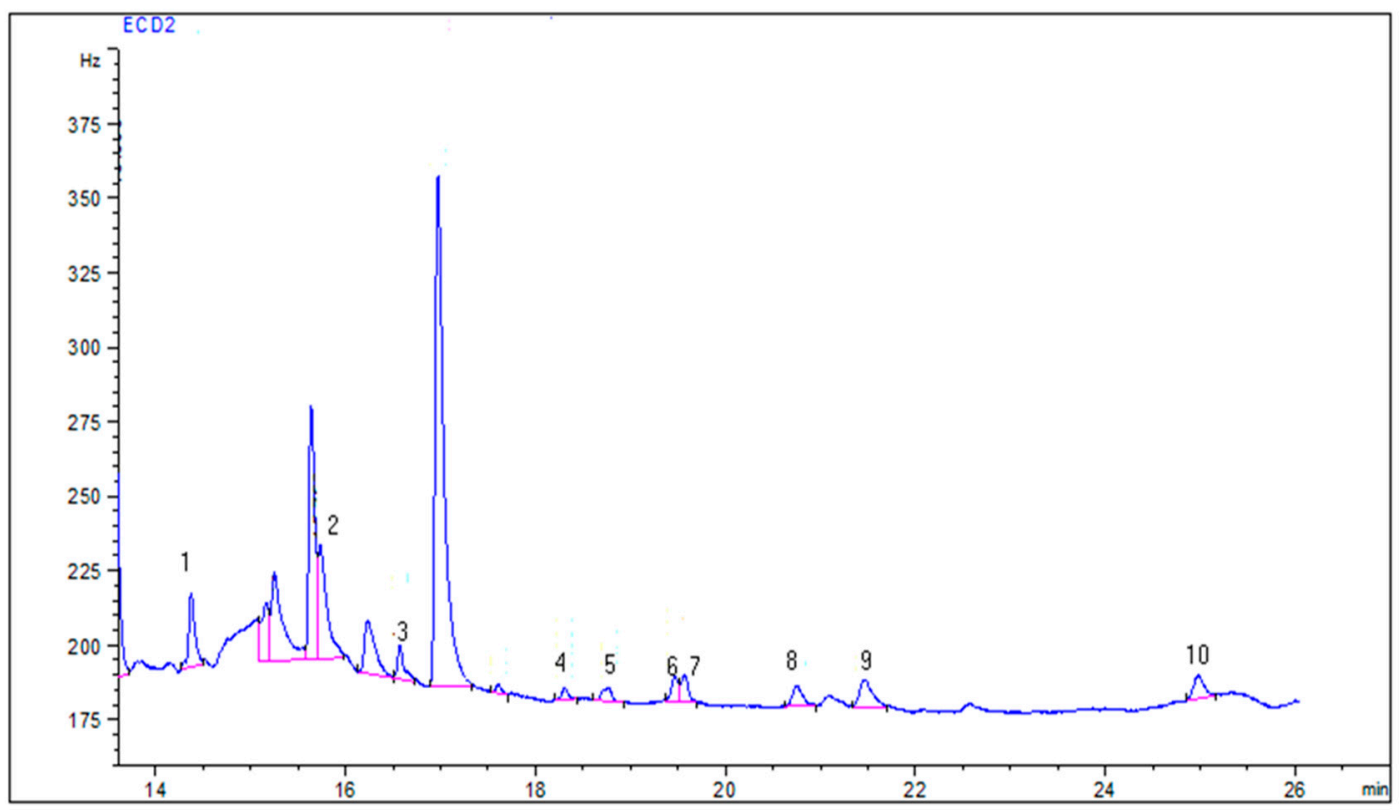

Figure 3. Representative Chromatogram and peaks identification of pesticides in surface water samples from Charsadda area: (1) $\gamma$-BHC, (2) heptachlor, (3) aldrin, (4) $\alpha$-chlordane, (5) endosulfan I, (6) 4,4'-DDE, (7) dieldrin, (8) endosulfan II, (9) Endrin aldehyde, (10) Endosulfan sulfate.

Table 4. Summary of selected pesticides contamination in surface water samples of Charsadda area.

\begin{tabular}{|c|c|c|c|c|}
\hline No. & Compound & Total Samples Tested & Contaminated Samples & Range $\left(\mu \mathrm{g} \mathrm{L}^{-1}\right)$ \\
\hline 1 & $\alpha-\mathrm{BHC}$ & 30 & 0 & nd * \\
\hline 2 & $\beta-\mathrm{BHC}$ & 30 & 0 & nd \\
\hline 3 & $\gamma-\mathrm{BHC}$ & 30 & 16 & nd-0.023 \\
\hline 4 & $\delta-\mathrm{BHC}$ & 30 & 0 & nd \\
\hline 5 & Heptachlor & 30 & 17 & nd-0.108 \\
\hline 6 & Aldrin & 30 & 14 & nd-0.014 \\
\hline 7 & Heptachlor epoxide & 30 & 0 & nd \\
\hline 8 & $\gamma$-Chlordane & 30 & 0 & nd \\
\hline 9 & $\alpha$-Chlordane & 30 & 0 & nd \\
\hline 10 & Endosulfan I & 30 & 2 & nd-0.005 \\
\hline 11 & $4,4^{\prime}-\mathrm{DDE}$ & 30 & 5 & nd -0.020 \\
\hline 12 & Dieldrin & 30 & 11 & nd-0.013 \\
\hline 13 & Endrin & 30 & 0 & nd \\
\hline 14 & Endosulfan II & 30 & 0 & nd \\
\hline 15 & $4,4^{\prime}-\mathrm{DDD}$ & 30 & 0 & nd \\
\hline 16 & Endrin aldehyde & 30 & 2 & 0.030 \\
\hline 17 & Endrin ketone & 30 & 0 & nd \\
\hline 18 & $4,4^{\prime}-\mathrm{DDT}$ & 30 & 0 & nd \\
\hline 19 & Endosulfan sulfate & 30 & 1 & 0.009 \\
\hline 20 & Methoxychlor & 30 & 0 & nd \\
\hline
\end{tabular}

nd *: Not detected.

Table 5 shows a comparison of pesticide contamination in the Charsadda area with the reported data of some other countries. The organochlorine pesticide residues in the surface water samples of Ghana have been reported in the range of $0.02-0.08 \mu \mathrm{g} \mathrm{L}^{-1}(\gamma$ -

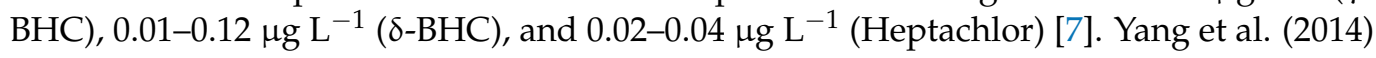


reported pesticide contamination in the surface water samples of China, with maximum concentrations of $0.003,0.006,0.003$ and $0.012 \mu \mathrm{g} \mathrm{L}^{-1}$ for $\alpha$-BHC, $\beta$-BHC, $\gamma$-BHC, and heptachlor, respectively [46]. Liu et al. (2013) identified pesticide contamination in surface water samples of Lake Chaohu, China, with maximum concentrations of $0.003 \mu \mathrm{g} \mathrm{L}^{-1}$ $(\alpha-\mathrm{BHC}), 0.009 \mu \mathrm{g} \mathrm{L}{ }^{-1}$ ( $\beta$-BHC), $0.003 \mu \mathrm{g} \mathrm{L}-1$ ( $\gamma$-BHC), $0.001 \mu \mathrm{g} \mathrm{L}^{-1}$ (heptachlor) and 0.001 $\mu \mathrm{g} \mathrm{L}^{-1}$ (aldrin) [8]. However, Golfinopoulos et al. (2003) reported pesticide contamination in surface water samples of Northern Greece with maximum concentrations of 0.031, 0.096, $0.081,0.189,0.020$ and $0.101 \mu \mathrm{g} \mathrm{L}^{-1}$ for $\alpha$-BHC, $\beta$-BHC, $\gamma$-BHC, $\delta$-BHC, heptachlor and aldrin, respectively [19].

Table 5. Comparison of pesticide contamination concentrations $\left(\mu \mathrm{g} \mathrm{L}^{-1}\right)$ with the reported data.

\begin{tabular}{|c|c|c|c|c|c|}
\hline Compound & Present Study & $\begin{array}{l}\text { Kuranchie- } \\
\text { Mensah et al., } \\
2012\end{array}$ & Yang et al., 2014 & Liu et al., 2013 & $\begin{array}{l}\text { Golfinopoulos } \\
\text { et al., } 2003\end{array}$ \\
\hline$\alpha-\mathrm{BHC}$ & nd * & - & nd-0.003 & nd-0.003 & nd-0.131 \\
\hline$\beta-\mathrm{BHC}$ & nd & - & nd -0.006 & nd-0.009 & nd -0.096 \\
\hline$\gamma-\mathrm{BHC}$ & nd -0.023 & $0.02-0.08$ & nd -0.003 & nd-0.003 & nd-0.081 \\
\hline$\delta-\mathrm{BHC}$ & nd & $0.01-0.12$ & nd -0.010 & - & nd-0.189 \\
\hline Heptachlor & nd-0.108 & $0.02-0.04$ & nd-0.012 & nd-0.001 & nd -0.020 \\
\hline Aldrin & nd-0.014 & $0.01-0.02$ & - & nd-0.001 & nd-0.101 \\
\hline$\gamma$-Chlordane & nd & $0.01-0.12$ & - & nd-0.002 & - \\
\hline$\alpha$-Chlordane & nd & - & - & nd-0.001 & - \\
\hline Endosulfan I & nd-0.005 & $0.01-0.04$ & nd-0.010 & nd-0.004 & nd-0.020 \\
\hline $4,4^{\prime}-\mathrm{DDE}$ & nd-0.020 & nd & nd-0.005 & nd-0.001 & nd- -0.064 \\
\hline Dieldrin & nd -0.013 & nd & - & nd-0.002 & nd-0.039 \\
\hline Endrin & nd & $0.01-0.03$ & - & nd-0.004 & nd \\
\hline Endosulfan II & nd & - & nd-0.013 & - & nd-0.022 \\
\hline $4,4^{\prime}-\mathrm{DDD}$ & nd & - & nd-0.005 & nd-0.001 & nd \\
\hline Endrin aldehyde & 0.030 & $0.05-0.15$ & - & - & nd -0.080 \\
\hline Endrin ketone & nd & nd & - & - & nd \\
\hline $4,4^{\prime}$-DDT & nd & $0.01-0.02$ & nd-0.014 & nd-0.010 & nd-0.035 \\
\hline Endosulfan sulfate & 0.009 & $0.11-0.26$ & - & - & nd -0.058 \\
\hline Methoxychlor & nd & nd & - & nd-0.018 & nd \\
\hline
\end{tabular}

Lindane $(\gamma$-BHC) has been used to treat food crops, forestry products, seeds and soil, and to treat pets and livestock. It was applied largely to cotton, coffee, cocoa, sugar cane and other crops. BHC isomers can undergo long-range transport and can be deposited into aquatic systems, where they can bioaccumulate in the food chain. Heptachlor has been used to kill soil insects and termites, to control grasshoppers, cotton insects and some crop pests, particularly those infecting corn. Aldrin and dieldrin are strongly related to each other. They were counted for a number of cases that produced the mortality of many wild life species, because following the application of aldrin in the fields, it rapidly changes to dieldrin [47].

The pesticides endosulfan I, 4,4'-DDE, endrin aldehyde and endosulfan sulfate were detected only in 2, 5, 2 and 1 surface water samples, with maximum concentrations of 0.005 , $0.020,0.030$ and $0.009 \mu \mathrm{g} \mathrm{L}^{-1}$ in the Charsadda area, respectively. The Australian guideline values for the pesticides endosulfan I, 4, $4^{\prime}$-DDE, 4, $4^{\prime}$-DDT, methoxychlor and endosulfan sulfate are $0.05,0.06,0.06,0.2$ and $0.5 \mu \mathrm{g} \mathrm{L}{ }^{-1}$, respectively. The endosulfan I was more dominant than the other endosulfans. The 4,4-DDE is the byproduct of DDT degradation and is more stable in the environment. None of the other pesticides in this study were detected in any of the surface water samples collected from the Charsadda area.

Kuranchie-Mensah et al. (2012) identified concentrations of various pesticides in surface water samples from Ghana in the range of $0.01-0.04 \mu \mathrm{g} \mathrm{L}{ }^{-1}$ (endosulfan I), 0.01-0.02 $\mu \mathrm{g} \mathrm{L}^{-1}$ (4,4-DDT), 0.05-0.15 $\mu \mathrm{g} \mathrm{L}^{-1}$ (endrin aldehyde) and 0.11-0.26 $\mu \mathrm{g} \mathrm{L}^{-1}$ (endosulfan sulfate) [7]. Golfinopoulos et al. (2003) identified contamination from the pesticides endo- 
sulfan I, 4, $4^{\prime}$-DDE, endrin aldehyde, 4, $4^{\prime}$-DDT and endosulfan sulfate in the surface water samples of Northern Greece, with maximum concentrations of 0.020, 0.064, 0.080, 0.035 and $0.058 \mu \mathrm{g} \mathrm{L}^{-1}$, respectively [19]. However, Liu et al. (2013) reported pesticide contamination from endosulfan I, 4,4-DDE, 4,4-DDD, 4,4-DDT and methoxychlor in the surface water samples of Lake Chaohu, China with maximum concentrations of 0.004, 0.001, 0.001, 0.010 and $0.018 \mu \mathrm{g} \mathrm{L}^{-1}$, respectively [8]. Yang et al. (2014) also reported organochlorine pesticide contamination in the surface water samples of China with maximum concentration of $0.010,0.005,0.013$ and $0.014 \mu \mathrm{g} \mathrm{L}^{-1}$ for endosulfan I, 4, 4-DDE, endosulfan II and 4,4-DDT, respectively [46].

All these studies show that pesticide contamination is a serious threat to human health and the environment. Therefore, efficient analytical and extraction methods are necessary to determine pesticide contamination in environmental samples. The analytical parameters studied with the SPME-GC-ECD method showed good percent recoveries, low detection limits and acceptable linear correlation, making them suitable for application in the analysis of water samples using the solid-phase micro-extraction (SPME) technique. This method allows a significant decrease in the volume of sample extracted, organic solvent consumption, and sample handling time in comparison with classical liquid-liquid extraction (LLE), or solid phase extraction (SPE) that has been commonly used in the analysis of pesticides in waters.

\subsection{Health Risk Assessment of OCPs in Water Samples}

Underground water i.e., pressure pumped and hand pumped water is mostly used for drinking purposes in the Charsadda district. A health risk assessment model [42] was used to calculate health risks from underground drinking water for adults and children. Some OCPs were present and some were not detected in the underground water samples of Charsadda district. The health risk levels caused due to OCPs were calculated for the maximum values of contaminants present in the underground drinking water for adults and children.

Table 1 showed the summary statistics for the health risks that may be associated with OCP contaminants present in the water samples of the Charsadda district. For adults, the cancer risk from surface water ranged from 0 to $0.96 \times 10^{-6}$ for $\gamma$-BHC, 0 to $15.53 \times$ $10^{-6}$ for heptachlor and 0 to $7.61 \times 10^{-6}$ for aldrin. The cancer risk for surface water from $4,4^{\prime}$-DDE and dieldrin ranged from 0 to $0.16 \times 10^{-6}$ and 0 to $8.69 \times 10^{-6}$, respectively.

Similarly, for children, the cancer risk from surface water due to $\gamma$-BHC, heptachlor and aldrin ranged from 0 to $2.05 \times 10^{-6}, 0$ to $33.29 \times 10^{-6}$ and 0 to $16.30 \times 10^{-6}$, respectively.

However, the cancer risk from surface water ranged from 0 to $0.47 \times 10^{-6}$ for $4,4^{\prime}$ DDE and 0 to $14.25 \times 10^{-6}$ for dieldrin. In most of the water samples, the cancer risk from heptachlor, aldrin and dieldrin for adults and children was negligible, however, in a few samples it was higher than the acceptable risk level $\left(1 \times 10^{-6}\right)$ recommended for carcinogens by the US EPA. The concentrations of these OCPs in the water samples indicates that, in most of the Charsadda district, the water may not pose any serious cancer risk to the local population, especially to children, and that the majority of the water samples in the area were suitable for drinking. However, it is essential to prevent new input sources of these OCPs in the surface and underground water to ensure safe drinking water.

Cancer risk due to each pollutant in the water samples from Charsadda district was in the order of heptachlor $>$ aldrin $>$ dieldrin. In all the water samples from Charsadda district, the cancer risk from $\alpha$-BHC, $\beta$-BHC, endosulfan I, 4,4-DDE, endrin, 4, $4^{\prime}$-DDT, endrin aldehyde, endrin ketone, $\gamma$-chlordane, $\alpha$-chlordane, $4,4^{\prime}$-DDE, endosulfan sulfate and methoxychlor was either not detected, or lower than the acceptable risk level $(1 \times$ $10^{-6}$ ) recommended for carcinogens by US EPA.

The hazard quotients were also estimated according to the assessment model for individuals based on the maximum contamination value of OCPs in water samples from 
Charsadda district. When the ratio of HQ increases above 1 , then it may have adverse effects on human health [45]. The non-carcinogenic risks from heptachlor, aldrin and dieldrin in the water samples from Charsadda district for children was somewhat higher than 1, which is the value recommended by US EPA, 1986. The non-carcinogenic risk from each pollutant in the water samples of the Charsadda district was in the order of heptachlor $>$ aldrin $>$ dieldrin $>\gamma$-BHC. Non-carcinogenic risk from $\alpha$-BHC, $\beta$-BHC, endosulfan I, 4, 4-DDE, endrin, 4, 4'-DDT, endrin aldehyde, endrin ketone, $\gamma$-chlordane, $\alpha$-chlordane, $4,4^{\prime}$-DDE, endosulfan sulfate and methoxychlor was not found in water samples from Charsadda district.

\section{Conclusions}

In this study, SPME coupled to the GC-ECD method was successfully developed for the extraction and determination of 20 chlorinated pesticides in surface water samples. The SPME method is fast, effective, simple, more environment friendly and decreases expenditures and time required for sample preparation and analysis. It is a good alternative to conventional sample extraction techniques such as liquid-liquid extraction (LLE) and solid phase extraction (SPE) without using expensive and toxic solvents or expensive extraction equipment. The SPME-GC-ECD method showed high extraction efficiency, good percent recoveries (87.5\% to $106.0 \%$ ) and acceptable LODs $\left(0.002\right.$ to $\left.0.03 \mu \mathrm{g} \mathrm{L}^{-1}\right)$ for all 20 chlorinated pesticides, which were much lower than their maximum permissible contamination levels. These results indicated that this system is a sensitive, cheaper and simpler alternative to mass spectrometry for assessment the presence of organochlorine pesticides residues in water samples. About $50 \%$ of the surface water samples collected from Charsadda district were found to be contaminated with pesticides such as $\gamma$-BHC, heptachlor, aldrin and dieldrin. Contamination from the major pesticides was found at maximum values of $0.023 \mu \mathrm{g} \mathrm{L}{ }^{-1}$ ( $\gamma$-BHC), $0.108 \mu \mathrm{g} \mathrm{L}{ }^{-1}$ (heptachlor), $0.014 \mu \mathrm{g} \mathrm{L}{ }^{-1}$ (aldrin) and $0.013 \mu \mathrm{g} \mathrm{L}^{-1}$ (dieldrin) in the surface water samples of the Charsadda area. For adults, the cancer risk from water due to contamination of various pesticides ranged from 0 to $15.53 \times 10^{-6} \mu \mathrm{g} \mathrm{L}^{-1}$. The non-carcinogenic risk found from each pollutant in the water samples was in the order of aldrin $>$ dieldrin $>$ heptachlor $>\gamma$-BHC. Similarly, for children, the cancer risk ranged from 0 to $33.29 \times 10^{-6} \mu \mathrm{g} \mathrm{L}{ }^{-1}$ and non-carcinogenic risk was found in the order of heptachlor $>$ aldrin $>$ dieldrin $>\gamma$-BHC. The SPME coupled to GC-ECD has been found to be an excellent approach for the analysis of chlorinated pesticides in water samples. Author Contributions: Conceptualization, M.I.; methodology, N.u.R., Z.V.-G., G.R.;

software, S.A.; validation, I.Z., M.S.K. and M.Z.; formal analysis, A.K., J.B.; investigation, I.Z., A.K., N.P.; resources, M.Z.; data curation, N.R.; writing—original draft preparation, N.u.A., I.Z., S.M.M.S., M.W. and Y.J.; writing-review and editing, I.Z.; visualization, L.A.S.; supervision, M.Z.; project administration, M.Z.; funding acquisition, M.Z. All authors have read and agreed to the published version of the manuscript.

Funding: This research was funded by project nr T190087MIMV and European Commission, MLTKT19481R “Identifying best available technologies for decentralized wastewater treatment and resource recovery for India, SLTKT20427 “Sewage sludge treatment from heavy metals, emerging pollutants and recovery of metals by fungi and by project KIK 15392 and 15401 by European Commission.

Institutional Review Board Statement: Not applicable.

Informed Consent Statement: Not applicable.

Data Availability Statement: Not applicable.

Conflicts of Interest: The authors declare no conflict of interest. The funders had no role in the design of the study; in the collection, analyses, or interpretation of data; in the writing of the manuscript, or in the decision to publish the results.

\section{References}

1. Ismail, M.; Khan, H.M.; Sayed, M.; Cooper, W.J. Advanced oxidation for the treatment of chlorpyrifos in aqueous solution. Chemosphere 2013, 93, 645-651. [CrossRef] [PubMed] 
2. Hildebrandt, A.; Guillamon, M.; Lacorte, S.; Tauler, R.; Barcelo, D. Impact of pesticides used in agriculture and vineyards to surface and groundwater quality (North Spain). Water Res. 2008, 42, 3315-3326. [CrossRef]

3. Ali, N.; Ali, L.N.; Eqani, M.A.S.; Ismail, I.M.I.; Malarvannan, G.; Kadi, M.W.; Basahi, J.M.A.; Covaci, A. Organohalogenated contaminants in sediments and bivalves from the Northern Arabian Gulf. Ecotoxicol. Environ. Saf. 2015, 122, 432-439. [CrossRef] [PubMed]

4. Gao, H.; Gao, X.; Cao, Y.; Xu, L.; Jia, L. Influence of Hydroxypropyl- $\beta$-cyclodextrin on the Extraction and Biodegradation of p, $\mathrm{p}^{\prime}$-DDT, o, $\mathrm{p}^{\prime}$-DDT, p, $\mathrm{p}^{\prime}$-DDD, and p, $\mathrm{p}^{\prime}$-DDE in Soils. Water Air Soil Pollut. 2015, 226, 208. [CrossRef]

5. Guéguen, F.; Stille, P.; Millet, M. Persistent organic pollutants in the atmosphere from urban and industrial environments in the Rhine Valley. Environ. Sci. Pollut. Res. 2013, 20, 3852-3862. [CrossRef]

6. Bonansea, R.I.; Ame, M.V.; Wunderlin, D.A. Determination of priority pesticides in water samples combining SPE and SPME coupled to GC-MS. A case study:Suquía River basin (Argentina). Chemosphere 2013, 90, 1860-1869. [CrossRef]

7. Kuranchie-mensah, H.; Atiemo, S.M.; Maud, L.; Palm, L.M.; Blankson-arthur, S.; Tuto, A.O.; Fosu, P. Determination of organochlorine pesticide residue in sediment and water from the Densu river basin, Ghana. Chemosphere 2012, 86, 286-292. [CrossRef] [PubMed]

8. Liu, W.X.; He, W.; Qin, N.; Kong, X.; He, Q.; Ouyang, H.; Xu, F. The residues, distribution and partition of organochlorine pesticides in the water, suspended solids, and sediments from a large Chinese lake (Lake Chaohu) during the high water level period. Environ. Sci. Pollut. Res. 2013, 20, 2033-2045. [CrossRef]

9. Seebunrueng, K.; Santaladchaiyakit, Y.; Srijaranai, S. Vortex-assisted low density solvent based demulsified dispersive liquidliquid microextraction and high-performance liquid chromatography for the determination of organophosphorus pesticides in water samples. Chemosphere 2014, 103, 51-58. [CrossRef]

10. Teng, Y.; Li, J.; Wu, J.; Lu, S.; Wang, Y.; Chen, H. Environmental distribution and associated human health risk due to trace elements and organic compounds in soil in Jiangxi province, China. Ecotoxicol. Environ. Saf. 2015, 122, 406-416. [CrossRef]

11. Tariq, M.I.; Afzal, S.; Hussain, I.; Sultana, N. Pesticides exposure in Pakistan: A review. Environ. Int. 2007, 33, 1107-1122. [CrossRef]

12. Tindall, J.A.; Chen, A. Variables that Affect Agricultural Chemicals in Groundwater in Nebraska. Water Air Soil Pollut. 2014, 225, 1862. [CrossRef]

13. Younas, A.; Hilber, I.; Rehman, S. Former DDT factory in Pakistan revisited for remediation: Severe DDT concentrations in soils and plants from within the area. Environ. Sci. Pollut. Res. 2013, 20, 1966-1976. [CrossRef] [PubMed]

14. Zhou, Q.; Wang, J.; Meng, B.; Cheng, J.; Lin, G.; Chen, J.; Zheng, D.; Yu, Y. Distribution and sources of organochlorine pesticides in agricultural soils from central China. Ecotoxicol. Environ. Saf. 2013, 93, 163-170. [CrossRef] [PubMed]

15. Pitacco, V.; Mistri, M.; Ferrari, C.R.; Sfriso, A.; Sfriso, A.A.; Munari, C. Multiannual Trend of Micro-Pollutants in Sedimentsand Benthic Community Response in a Mediterranean Lagoon (Sacca di Goro, Italy). Water 2020, 12, 1074. [CrossRef]

16. Curtean-Banaduc, A.; Burcea, A.; Mihu, B.D. The Benthic Trophic Corner StoneCompartment in POPs Transfer fromAbiotic Environment to HigherTrophic Levels-Trichoptera andEphemeroptera Pre-Alert IndicatorRole. Water 2021, 13, 1778. [CrossRef]

17. Abbasi1, Y.; Mannaerts, C.M.; Makau, W. Modeling Pesticide and Sediment Transport in theMalewa River Basin (Kenya) Using SWAT. Water 2019, 11, 87. [CrossRef]

18. Dong, C.; Zeng, Z.; Yang, M. Determination of organochlorine pesticides and their derivations in water after HS-SPME using polymethylphenylvinylsiloxane-coated fiber by GC-ECD. Water Res. 2005, 39, 4204-4210. [CrossRef] [PubMed]

19. Golfinopoulos, S.K.; Nikolaou, A.D.; Kostopoulou, M.N.; Xilourgidis, N.K.; Vagi, M.C.; Lekkas, D.T. Organochlorine pesticides in the surface waters of Northern Greece. Chemosphere 2003, 50, 507-516. [CrossRef]

20. Fung, C.N.; Zheng, G.J.; Connell, D.W.; Zhang, X.; Wong, H.L.; Giesy, J.P.; Fang, Z.; Lam, P.K. Risks posed by trace organic contaminants in coastal sediments in the Pearl River Delta, China. Mar. Pollut. Bull. 2005, 50, 1036-1049. [CrossRef]

21. Santhi, V.A.; Hairin, T.; Mustafa, A.M. Simultaneous determination of organochlorine pesticides and bisphenol A in edible marine biota by GC-S. Chemosphere 2012, 86, 1066-1107. [CrossRef]

22. Sankararamakrishnan, N.; Kumar Sharma, A.; Sanghi, R. Organochlorine and organophosphorous pesticide residues in ground water and surface waters of Kanpur, Uttar Pradesh, India. Environ. Int. 2005, 31, 113-120. [CrossRef] [PubMed]

23. Di Bella, G.; Licata, P.; Bruzzese, A.; Naccari, C.; Trombetta, D.; Lo Turco, V.; Dugo, G.; Richetti, A.; Naccari, F. Levels and congener pattern of polychlorinated biphenyl and organochlorine pesticide residues in bluefin tuna (Thunnus thynnus) from the Straits of Messina (Sicily, Italy). Environ. Int. 2006, 32, 705-710. [CrossRef]

24. PES. Pakistan Economic Survey: 2011-2012; Economic Advisor's Wing; Finance Division, Government of Pakistan: Islamaabad, Pakistan, 2012.

25. ERS Employment \& Research Section, Planning \& Development Division, Government of Pakistan, Islamabad. Pre-Feasibility Study for Pesticide Industry; International Asset Management Company Ltd.: Karachi, Pakistan, May 2006.

26. Khan, M.S. Pakistan crop protection market. PAPA Bull. 1998, 9, 7-9.

27. Eavy, A.L.; Ahmed, F.; Buriro, A.S. Final report on integrated pest/production/plant management (IPM). Development program ARP-II Sindh submitted by Winrock international institute for agricultural development. Dir. Gen. Agric. Res. 1995, 2, 1-27.

28. WHO. Public Health Impact of Pesticides Used in Agriculture; WHO: Geneva, Switzerland, 1990.

29. Tempowski, J. (WHO) Personal Communication; WHO: Geneva, Switzerland, 10 January 2012. 
30. Prüss-Ustün, A.; Vickers, C.; Haefliger, P.; Bertollini, R. Knowns and Unknowns on Burden of Disease due to Chemicals: A Systematic Review. Environ. Health 2011, 10, 9. [CrossRef] [PubMed]

31. WHO. The Global Burden of Disease-2004 Update; WHO: Geneva, Switzerland, 2008.

32. Ismail, M.; Sayed, M.; Khan, H.M.; Cooper, W.J. Analysis of Pesticides in Water Samples and Removal of Monocrotophos by $\gamma$-Irradiation. J. Anal. Bioanal. Tech. 2014, 5, 181-191.

33. Richardson, S.D.; Ternes, T.A. Water Analysis: Emerging Contaminants and Current Issues. Anal. Chem. 2011, 83, 4614-4648. [CrossRef]

34. Esther, M.; Padrón, T.; Afonso-olivares, C.; Sosa-ferrera, Z.; Santana-rodríguez, J.J.; Química, D.D. Microextraction Techniques Coupled to Liquid Chromatography with Mass Spectrometry for the Determination of Organic Micropollutants in Environmental Water Samples. Molecule 2014, 19, 10320-10349.

35. Boussahel, R.; Bouland, S.; Moussaoui, K.M.; Baudu, M.; Montiel, A. Determination of chlorinated pesticides in water by SPME/GC. Water Res. 2002, 36, 1909-1911. [CrossRef]

36. Perez-Trujillo, J.P.; Frias, S.; Conde, J.E.; Rodriguez-Delgado, M.A. Comparison of different coatings in solid-phase microextraction for the determination of organochlorine pesticides in ground water. J. Chromatogr. A 2002, 963, 95-105. [CrossRef]

37. Phan, K.; Sthiannopkao, S.; Kim, K.W.; Wong, M.H.; Sao, V.; Hashim, J.H. Health risk assessment of inorganic arsenic intake of Cambodia residents through groundwater drinking pathway. Water Res. 2010, 44, 5777-5788. [CrossRef]

38. Hu, Y.; Qi, S.H.; Zhang, J.P.; Tan, L.Z.; Zhang, J.Q.; Wang, Y.H. Assessment of organochlorine pesticides contamination in underground rivers in Chongqing, Southwest China. J. Geochem. Explor. 2011, 111, 47-55. [CrossRef]

39. IRIS (Integrated Risk Information System). US Environmental Protection Agency: Cincinnati, OH, USA, 2005. Available online: http:/ / www.epa.gov/iris (accessed on 1 September 2021).

40. US EPA. Risk Assessment Guidance for Superfund. Volume I: Human Health Evaluation Manual (Part A); EPA/540/1-89/002; Office of Emergency and Remedial Response: Washington, DC, USA, 1989.

41. US EPA. Guidelines for the Health Risk Assessment of Chemical Mixtures; Office of Emergency and Remedial Response: Washington DC, USA, 1986.

42. US EPA. Exposure Factors Handbook; EPA/600/P-95/002Fa; Office of Research and Development National Center for Environmental Assessment: Washington, DC, USA, 1997.

43. Cortada, C.; Vidal, L.; Pastor, R.; Santiago, N.; Canals, A. Determination of organochlorine pesticides in water samples by dispersive liquid-liquid microextraction coupled to gas chromatography-mass spectrometry. Anal. Chim. Acta 2009, 649, $218-221$. [CrossRef]

44. U.S. EPA. Method 525.2, Determination of Organic Compounds in Drinking Water by Liquid-Solid Extraction and Capillary Column Gas Chromatography/Mass Spectrometry; U.S. Environmental Protection Agency: Washington, DC, USA, 1995.

45. Graña, E.; Fernández-Martínez, G.; Fernández-Villarrenaga, V.; Turnes-Carou, M.I.; Muniategui-Lorenzo, S.; López-Mahía, P. A study of large-volume on-column injection GC-ECD for the ultratrace analysis of organochlorine pesticides in water. Talanta 2009, 78, 764-771. [CrossRef]

46. Yang, Y.; Yun, X.; Liu, M.; Jiang, Y.; Li, Q.X.; Wang, J. Concentrations, distributions, sources, and risk assessment of organochlorine pesticides in surface water of the East Lake, China. Environ. Sci. Pollut. Res. 2014, 21, 3041-3050. [CrossRef] [PubMed]

47. Turgut, $\mathrm{C}$. The contamination with organochlorine pesticides and heavy metals in surface water in Kucuk Menderes River in Turkey, 2000-2002. Environ. Int. 2003, 29, 29-32. [CrossRef] 